\begin{tabular}{c} 
Volume and Issues Obtainable at Center for Sustainability Research and Consultancy \\
Journal of Accounting and Finance in Emerging Economies \\
ISSN: 2519-0318ISSN (E) 2518-8488 \\
Volume 2: Issue 2 December 2016 \\
CSRC \\
Journal homepage: $\underline{\text { www.publishing.globalcsrc.org/jafee }}$ \\
\hline
\end{tabular}

\title{
Impact of Net Stable Funding Ratio Regulations on Net Interest Margin: A Multi- Country Comparative Analysis
}

\author{
${ }^{1}$ Rehana Kouser, ${ }^{2}$ Zeeshan Mahmood, ${ }^{3}$ Ulfat Abbas \\ ${ }^{1}$ Professor, Department of Commerce, Bahauddin Zakariya University Multan, Pakistan. \\ rehanakousar@bzu.edu.pk \\ ${ }^{2}$ Assistant Professor, Department of Commerce, Bahauddin Zakariya University Multan, Pakistan. \\ zeeshanmahmood@bzu.edu.pk \\ ${ }^{3}$ MPhil Scholar, Department of Commerce, Bahauddin Zakariya University Multan, Pakistan \\ ua19880@gmail.com
}

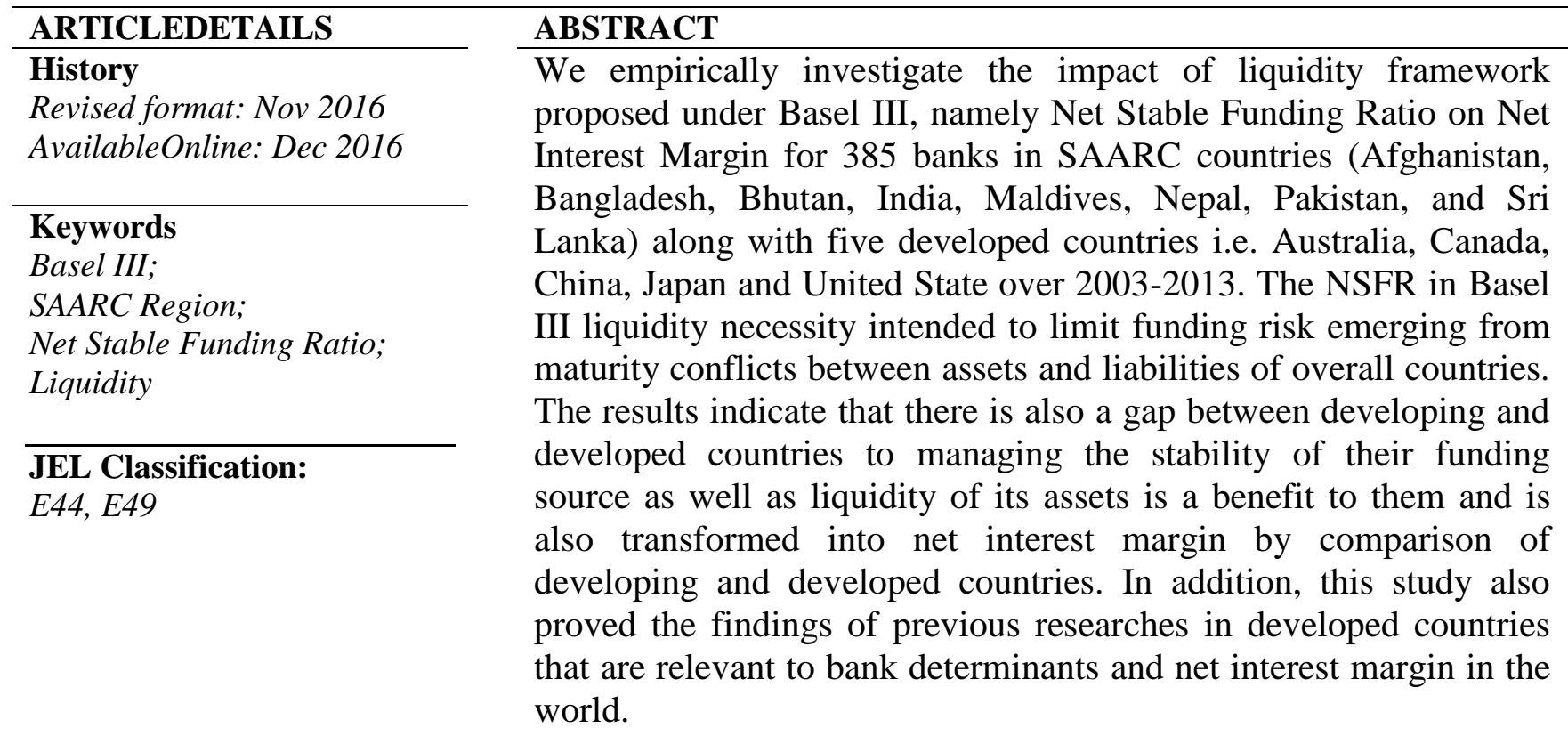

(C) 2016 The authors, under a Creative Commons Attribution-

NonCommercial 4.0

Corresponding author's email address:ua19880@gmail.com

Recommended citation:Kouser, R., Mahmood, Z., Abbas, U., (2016).Impact of Net Stable Funding Ratio Regulations on Net Interest Margin: A Multi-Country Comparative Analysis.Journal of Accounting and Finance in Emerging Economies, 2(2) 93-102

\section{Introduction}

When markets collapse, the plans paved into future can be demolished. As the economies are becoming increasingly globalized and mutually dependent hence the upshots of a banking crisis are transmittable away from the border of countries. The increase in cross-border trade along with the collapse of US 
mortgage market 2007-2008 has demonstrated that financial globalization has advance in developing the sufficient global institutions with the objective to assist in managing globalization along with advancement of financial mechanisms (Stiglitz 2010, 151). As the upshot of recent financial market collapse 2007-2008 the banking regulation was refurbished, hence Basel III accord come into existence with an intention to be replaced by Basel II. By making amendments along with the requirements of capital Basel III, furthermorethere are two main funding' standards including liquidity coverage (LCR) as well as net stable funding ratio (NSFR). In short, the first standard deals with inflexible control of short term liquidity but other standard seeks to overcome the problem of difference in maturity between assets and liabilities of the banks.

The global financial crunch became a source of great turmoil for the banking institutions of developed countries. By making comparison among the collapses of global financial giants of developed economies, there was less number of bank crashes in developing economies. Hence, the emerging economies follow the catching up process of 2007-2008 global financial crises. This paper seeks to presents the first inclusive evaluation of the Net Stable Funding Ratio (NSFR) and estimates the ratio for the developed and developing economies by making a sharp comparison. In this research study, various strategies are observed for those financial institutions whose value is less than the threshold level, thus to meet NSFR and assess about impact these changes bring on Net Interest Margin a financial institution. The financial crisis of 2007-2009 witnessed that in various countries the displacement of wholesale funding markets of banks was the core reason for the sufferance of shortages of liquidity. The financial institutions were unable to overturn their debts as they financed long-term assets with debt of short -term thus making these banks most exposed to risk (Acharya and Merrouche, 2013; Huang and Ratnovski, 2011; Afonso et al., 2011; Diamond and Rajan, 2009; Gorton, 2009; Brunnermeier and Markus, 2009). However, NSFR deal with funding risk and is devised to endorse structural amendments developing profiles of risks for banks attend to be more stable by funding in longer-term assets. Banks which do not meet the NSFR require condensing assets entailing stable funding along with an increase in sources of stable funding. This empirical study draws attention to the tradeoffs between liquidity reforms, financial institution risk and profitability by making comparison among developing and developed countries. The NSFR is devised to promote banks for holding more high-quality of liquid assets and use stable sources to boost its funding. Such changes will enhance the buoyancy of banks in the periods of stress.

Preferably, micro-data is used by researchers to check the response of banks towards the Basel III liquidity requirements. Regrettably, still the data is not available not even for the national supervisors the data does not yet exist, even for national supervisors. So, we used bank scope data for the estimation of NSFR.

However, the trade-off results in lower the profitability of financial institution. Interest income will be lowered if the smaller quantities of illiquid assets are pledged along with the more assets of high quality. Although, in case of financing assets with long-term liabilities will cause to boost in interest expense. Hence, the follow-on turns down in net interest income together with the rise in interest bearing assets will provide a basis for the decline in NIMs. Financial institutions compliances to BCBS advocate that liquidity constraints might negatively influence the business models as well as profitability of financial institutions. Concerning about the possible unintended outcomes, the NSFR implementation process have been delayed by the regulators until 2018.

This paper presents the inclusive evaluation of the Net Stable Funding Ratio (NSFR). In this empirical study, we will delineate how NSFR is determined and ratio is estimated for the banks representing 5 developed countries (Australia, Canada, China, Japan and United State) and 7 developing countries 
(SAARC). For banks that are less the minimum threshold, we look for different strategies to meet the NSFR and assess the influence of these changes on bank net interest margins (NIMs). Further the comparison will be done between those developed and developing countries.

\section{LITERATURE REVIEW}

Generally, the concept of liquidity is three-fold; market liquidity, funding liquidity, and liquidity creation. Basically, the NSFR is proposed to target the funding liquidity issue by reducing funding risk take place due to mismatch between assets and liabilities, whereas the LCR deals with the liquidity risk by rising the number of bank holdings of high-quality including liquid assets.

However, while citing an extensive amount of literature, Berger and Bouwman (2009) claims that as banks exist for the reason as they generate liquidity and convert risk1. Liquidity formation refers to the stipulation of financing to the real economy. By funding comparatively illiquid assets with liquid liabilities, financial institutions generate liquidity on balance sheet. In addition to this, banks give an access to other options of financing by using operations of off-balance sheet for-example: loan commitments. Transformation of risk is also involving in this process. Consequently, the role of liquidity creation and risk transformation cause banks susceptible to both risks funding as well as the liquidity. By summarizing the broad literature on these issues, Strahan (2010) concurs that composition of bank balance sheet along with their right to use liquidity of central bank, government guarantees allow it an extra ordinary benefit in controlling these risks. However, the global financial crisis of 2007-2009 reveals flaws in banks risk management techniques and calls for new set of reforms which results in the form of BASELIII.

Although, The Basel III reforms may correspond to the foremost effort by international regulators to establish minimum liquidity standards (Standard \& Poor's, 2010), as the liquidity risk has long been the core reason in models of bank failure (Diamond and Dybvig, 1983), in addition to regulation of capital and narrow banking studies (Diamond and Rajan, 2001) and in case of financial corruption (Allen and Gale, 2000). Whereas to avert deposit defaults, deposit insurance is broadly considered as one of the solution, as shown the defaults that take placed all through the latest crisis occurred in wholesale funding markets including federal funds (Afonso et al.,2011), interbank markets (Acharya and Merrouche, 2013), repomarkets (Gorton, 2009) or securitized markets (Brunnermeier, 2009). For the regulation of liquidity various banking models are suggested. Diamond and Rajan (2001) argue liquidity creation might be reduced due to capital regulation reforms and narrow banking structure. Indeed, Acharya et al. (2011) research provides a model with the propositions for bank liquidity options from different crisis decision rules.

Even though interferences to determine banking crises takes place, however, liquidity support provided to botched banks or unconditional support to ongoing banks reduces motivations to hold liquidity. Yet again, liquidity reforms may alleviate the moral hazard dilemma other than with possible unintended up shots for the financial system.

Literature surrounds capital regulations provides mixed views on either the regulatory reforms escort banks to increase risk taking. However, the models in theoretical studies of Hellmann et al. (2000), Jeitschko and Jeung (2007), Milne (2002), and Repullo (2004), surrounded by others, argue the propositions are not simple enough as they depend on the competition level. The empirical research work also reveals mix analysis. González (2005), for instance, come across that regulatory constraints boost banks' risk-taking incentives by dropping their charter value, whilst Laeven and Levine (2009) claims that the relation is basically dependent on ownership structure of each bank. It can be concluded that the same regulation can give different outcome due to bank, industry or country features. 


\subsection{The Net Stable Funding Ratio}

The risk factor appears because of immaturity between assets and liabilities of the banks, Basel III requirement for liquidity is an innovative idea which suggested how to reduce the risk regarding funding of the banks. The ratio of available stable funding (ASF) to required stable funding of the financial institutions is termed as net stable funding ratio (NSFR). However, recognized funding

However, established funding involves all structures regarding equity and liability funding likely being more reliable, as supply of funds throughout one-year that is subsequent the circumstances of prevalent financial straining. For determining ASF, 0 to $100 \%$ factor's range is assigned to shape of liability and equity, then that percentages are multiplies to existing total groups as each and by summing up of combinations of these totals is the value of the ASF. The similar rule is followed for RSF in formula, according to rule every value is detained and finances through the funding institutions that is additionally multiplied by each group factor, when the weighted amount summation is the value of RSF. To increase the flexibility of the banking system, the Basel Committee introduced from July 2009 to December 2010 subsequent sequences of advancement is known as Basel III (BCBS, 2010b). The Basel Committee predicted two different standards for liquidity to deal with banks funding' requirements, introduced by Northern Rock (BCBS, 2010a).

The suggestions which published and observed in November 2009 early but this is released and customized in December 2010. In January 2013, the LCR standard and its schedule was reviewed but NSFR plans remained same (King, 2013). To raise need base funding of banks, the NSFR is a longerterm structural ratio, which addresses funding risk. The balance sheet items are covered by NSFR and it also compels banks to fund long-term liquid assets with long-term capital. Limits can be provided to the Currency mismatches and cross-border funding risk by the assets given credit in the ratio. The NSFR has not been personalized and the schedule for preliminary execution remains 1 January 2018 (King, 2013).

\section{Data and Empirical Estimation}

This section states the source of data used in our study for the empirical investigation, we used annual reports of banks to collect variables' data. We obtained data from financial statements and from Bank scope comprises, of commercial and investments banks for 11 years (2003-2013) for all calculation of variables. We took 5 developed countries (Australia, Canada, China, Japan and United State) and developing (SAARC) countries (Afghanistan, Pakistan, India, Sri-Lanka, Maldives, Bangladesh and Nepal) but Afghanistan excluded due to political instability. In this study, we investigate to compare the impact of NSFR on net interest margin in the SAARC and developed countries by using this data. Our sample size for developed countries is 1814 in SAARC countries and 3410 in developed countries as well. We used STATA v.13.o. For all type of analysis on this database and showed below.

\subsection{Variables Measurement}

A commonly used measure of profitability is Net Interest Margin (NIM) which is a determined by the difference between the interest income produced by banks and the amount of interest paid out to their lenders (for example, deposits), relative to the amount of their (interest-earning) assets. In the first group, we usedbank specific factors i.e. funding stability (NSFR) explained as above, Operating Efficiency (COST) measure as operating expenses to total revenue, Capital Strength (EQUITY) calculated as total equity to total assets and Bank Size (SIZE) measure as log of total assets of the banks. In the second group, we used two determinants of macro-economic variables to examine the effect of environment on profitability of banks which are Real Gross Domestic Product (RGDP) growth and the inflation rate (INF) annually. 
The econometric model is estimated using the following equation:

NIMit $=a_{0}+\beta N S F R$ it $+\phi$ COSTit $+\partial$ EQUITYit $+\psi$ SIZEit $+\eta$ INFLjt $+\omega$ RGDPjt $+\varepsilon i t$

where

$i$ denotes to an individual bank, $t$ denotes to financial year, NIM (Net Interest Margin) is the dependent variables in this equation. $\alpha$ is the intercept of the regression model; NSFRit, COSTit, EQUITYit, and SIZEit are the bank specific determinants for bank in this study, RGDPjt and INFjt are the macroeconomic variables on year $\mathrm{t}$, and eitis an error term in this equation. In this equation, $\mathrm{i}$ and $\mathrm{t}$ shows as a penal dataset in this model.

\subsection{Calculating the NSFR}

To deal with financial crisis period, the NSFR is developed to enhance the long-term flexibility by high availability of liquidity of banks. This standard requirement species to banks that there is stable funding for the arrangement of liabilities, assets and their off-balance sheets items. For the calculation of NSFR, is shown as under:

$$
N S F R=\frac{\text { Available stable funding }}{\text { Required stable funding }}
$$

There are two issues when calculating the NSFR. First, there are ambiguities in the guidelines of the Basel III accord which requires the use of judgment. Second, there are format and detail related gaps in the publicly available data that are required for the determination of the NSFR (Hong et al., 2014). Following the effort of King (2013), this made several assumptions regarding stable and less-stable categories for deposits and maturities among assets and liabilities. Below is the set of variables that we should compute ASFitandRSFitwith a brief description of each variable:

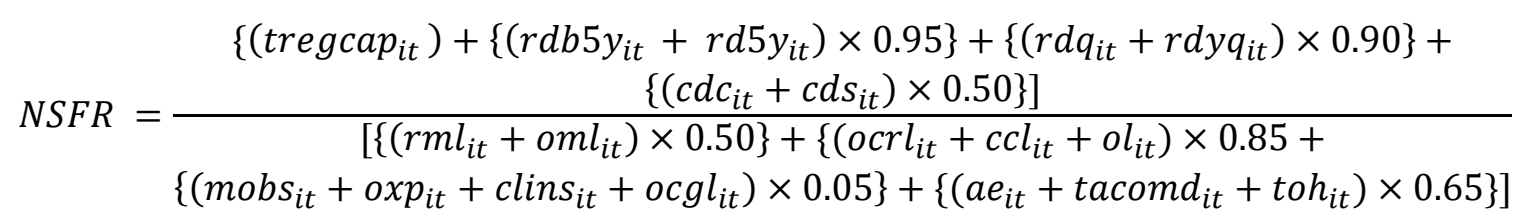

The NSFR numerator measures that sources of Available Stable Funding (ASF), with greater weight given to sources that are at least likely to disappear under stressed market situations. Equity, longer-term wholesale funding as well as longer-term liabilities are the most stable forms of funding', tracked by deposits and short-term wholesale funding maturing in less than one year. Interbank funding is not observed as a stable funding source and is given a $0 \%$ weight. The NSFR denominator shows a bank's Required Stable Funding (RSF), with a factor (or haircut) based on an asset's expected liquidation value under stressed conditions. Cash and securities with less than 1 year to maturity, and interbank claims do not have to be funded and have a factor of $0 \%$. Qualifying government debt with a $0 \%$ risk-weight is considered highly liquid and must only be funded at $5 \%$ of face value. Corporate loans and retail loans that mature within 1 year must be funded $50 \%$ and $85 \%$, respectively. Residential mortgages of any maturity as well as corporate loans greater than 1-year in maturity must be funded at $65 \%$. All remaining assets must be funded at $100 \%$.

For data screening process, we appliedtwo types of diagnostics tests in which the Breusch-Pagan Lagrange Multiplier (BPLM) test was firstly performed to decide either we should be used a random effects (RE) regression and pooled Ordinary Least Squares (POLS) regression on data. The values of LM test statistics is 0.310 for NIM in developed countries and 0.153 for SAARC countries as dependent variables, these confirm the absence of random effect in the database and it also provide evidence that if we use random effect estimation, this is not suitable method to test the relationship. Then we applied 
Hausman Test to test the fixed effect and random effect method to reject null hypothesis of random effect model which is ideal model for analysis in this study. This tells us two methods which are the POLS and Fixed Effect Regression to the relationship between bank specific determinants and profitability in this study.We used robust test for heteroscedasticity on this regression model in developing and developed countries model. The problem of heteroscedasticity can make the coefficient as insignificant in the regression model estimation.

\subsection{Descriptive Statistics:}

The table 1 and 2 show the descriptive statistics of the study which indicate data normality test. The means value of each variable should be greater than its standard deviation. The mean value of the variables lies between $0.4975604 \leq$ Mean $\leq 8.181748$ in SAARC and $0.5155287 \leq$ Mean $\leq 5.177132$ of developed countries and these are positive values. The standard deviation of each variable is less than its mean value which shows the data is normally distributed. NIM standard deviations are 2.790729 and 2.797408 which are less than its means of 4.26437, 4.258634 in SAARC and developed countries respectively. The minimum value of NIM is 1.11 and maximum value is 11.22 in overall sample. Wewinsorized all variables at 5\% except RGDP and INF to remove the outliers from this database. Further details of descriptive statistics of other variables are given below:

\begin{tabular}{|l|l|l|l|l|l|l|l|l|}
\hline Table 1: Descriptive Statistics: SAARC Countries \\
\hline Variable & Obs. & Mean & Std. Dev. & Min & $\mathbf{2 5 \%}$ & Median & $\mathbf{7 5 \%}$ & Max \\
\hline NIM & 1103 & 4.26437 & 2.790729 & 1.11 & 2.06 & 3.53 & 5.62 & 11.22 \\
\hline NSFR & 1133 & 0.926021 & 0.9073025 & 0 & 0.315633 & 0.59935 & 1.246575 & 3.386752 \\
\hline COST & 883 & 1.405391 & 1.134254 & 0.101351 & 0.580882 & 1.079268 & 1.912621 & 3.803921 \\
\hline EQUITY & 988 & .4974604 & .26818 & .100000 & .2163 & .525 & .694 & .998 \\
\hline SIZE & 981 & $4.34 \mathrm{E}+00$ & $9.01 \mathrm{E}-01$ & $2.69 \mathrm{E}+00$ & $3.58 \mathrm{E}+00$ & $4.38 \mathrm{E}+00$ & $5.09 \mathrm{E}+00$ & $5.87 \mathrm{E}+00$ \\
\hline RGDP & 1814 & $4.17 \mathrm{E}+11$ & $5.06 \mathrm{E}+11$ & $7.20 \mathrm{E}+08$ & $3.10 \mathrm{E}+10$ & $9.70 \mathrm{E}+10$ & $9.10 \mathrm{E}+11$ & $1.50 \mathrm{E}+12$ \\
\hline INF & 1812 & 8.181748 & 3.492036 & -18.1086 & 6.21765 & 7.80529 & 9.68505 & 22.5645 \\
\hline Table 2: Descriptive Statistics: Developed Countries & & & & \\
\hline Variable & Obs. & Mean & Std. Dev. & Min & $\mathbf{2 5 \%}$ & Median & $\mathbf{7 5 \%}$ & Max \\
\hline NIM & 2042 & 4.258634 & 2.797408 & 1.11 & 2.13 & 3.42 & 5.73 & 11.22 \\
\hline NSFR & 1829 & 0.712014 & 0.7964847 & 0 & 0.184505 & 0.451146 & 0.882296 & 3.38675 \\
\hline COST & 2191 & 2.496181 & 2.145229 & 0.127907 & 0.778571 & 1.834483 & 3.634146 & 6.904762 \\
\hline EQUITY & 2342 & .5155287 & .1894453 & .11 & .3711 & .5185 & .64 & .999 \\
\hline SIZE & 2341 & 5.177132 & 0.5620577 & 2.691159 & 4.807083 & 5.278998 & 5.633897 & 5.869927 \\
\hline RGDP & 3410 & $3.78 \mathrm{E}+12$ & $1.43 \mathrm{E}+12$ & $6.40 \mathrm{E}+11$ & $2.90 \mathrm{E}+12$ & $4.40 \mathrm{E}+12$ & $4.60 \mathrm{E}+12$ & $1.40 \mathrm{E}+13$ \\
\hline INF & 3410 & 1.591484 & 2.030528 & -1.34672 & -0.00828 & 1.37349 & 2.77074 & 5.86438 \\
\hline
\end{tabular}

\subsection{Correlation SAARC Countries}

The table 3 shows the pairwise correlation coefficients of the variables. The correlation tells about the relationship between two variables. According to results, if one-unit change in independent variable NSFR, the change will be there $1.06 \%$ and -4.74 in dependent variable NIM in SAARC and developed countries respectively. This correlation is very weak in both areas of the study because the funding regulations are not fully followed by the banks in them. There is negative correlation in developed at $1 \%$ level of significant in developed countries and positive relationship exist with NIM at 5\% level of significant in SAARC. The table 3 also defines that COST, EQUITY, INF have positive correlation with the value of $4.43 \%, 1.59 \%$ and $1.93 \%$ respectively with NIM but there is negative correlation with SIZE 
as well as RGDP with NIM at 5\% level of significance in SAARC. In developed countries, there is greater correlation exist in banks specific factors and macro-economic variables. The table 4 explains that COST, EQUITY and INF have correlation of $2.77 \%, 2.45 \%, 0.33 \%$ respectively at the significance level of 5\% but negative correlation is available in SIZE and RGDP with the value of $7.63 \%$ and 2.13 at 10 as well as $5 \%$ level of significance respectively.

\begin{tabular}{|c|c|c|c|c|c|c|c|}
\hline \multicolumn{8}{|c|}{ Table 3: Correlation SAARC Countries } \\
\hline Variable & NIM & NSFR & COST & EQUITY & SIZE & RGDP & INF \\
\hline NIM & 1 & & & & & & \\
\hline NSFR & $0.0106^{* * *}$ & 1 & & & & & \\
\hline COST & $0.0443 * *$ & $-0.0814^{*}$ & 1 & & & & \\
\hline EQUITY & $0.0159 * *$ & $-0.0289 * *$ & -0.0397 & 1 & & & \\
\hline SIZE & $-0.0455 * *$ & -0.1236 & $0.0144 * * *$ & -0.5785 & 1 & & \\
\hline RGDP & $-0.0335^{* *}$ & -0.2072 & $0.0981^{*}$ & -0.3132 & 0.7134 & 1 & \\
\hline INF & $0.0193 * *$ & $0.0499 * *$ & $0.0806^{*}$ & 0.1516 & $0.0217 * *$ & $0.0354 * *$ & 1 \\
\hline \multicolumn{8}{|c|}{ Table 4: Correlation Developed Countries } \\
\hline Variable & NIM & NSFR & COST & EQUITY & SIZE & RGDP & INF \\
\hline NIM & 1 & & & & & & \\
\hline NSFR & $-0.0474 * *$ & 1 & & & & & \\
\hline COST & $0.0277 * *$ & $0.0252 * *$ & 1 & & & & \\
\hline EQUITY & $0.0245^{* *}$ & $-0.0701 *$ & -0.1024 & 1 & & & \\
\hline SIZE & $-0.0763 *$ & $0.0787 *$ & -0.1125 & -0.4529 & 1 & & \\
\hline RGDP & $-0.0213 * *$ & 0.1257 & $0.0973^{*}$ & $-0.0505^{*}$ & $0.0547 * *$ & 1 & \\
\hline INF & $0.0033 * * *$ & -0.1143 & -0.2838 & 0.2576 & -0.2278 & $-0.3162 *$ & 1 \\
\hline
\end{tabular}

\section{Regression Results}

Based on the result of OLS regression explained in Table 5, the NSFR have negative effect on banks profitability in developed countries and it is significant. This result suggested that the BASEL III requirements of stable fundings have negative connection with profitability of the banks in developed countries but there is positive association with profitability in SAARC, this study is consistent with Jiraporn et al., (2014). Operating efficiency have positive relationship with NIM but it is insignificant in both regions, that show high level of cost efficiency leads to high profitability of the banks. These findings are confirmed with Hong et al., (2014). The capital strength is positively associated with banks performance in SAARC that confirms the study of Mohd Said, (2014) but negative association in the bank's profitability of developed countries. The coefficient of the SIZE indicates the positive relationship with profitability of the banks but it is insignificant in SAARC. This validates the 'toobig to fail' phenomena wherein larger banks are more profitablerisk-management tools as contended by Hankenes and Schnabel(2011). In the developed countries, there is negative association with profitability which show big banks are less profitable as compare to small banks. Finally, both estimations show that the effect of macroeconomic factors on profitability is not significant except RGDP in SAARC and hence do not provide support to the argument of positive association between macroeconomic conditions and financial sectors performance which is consistent with the findings of Dietrich et. al (2010). The table 5 also shows the coefficient of determination which is $2.8 \%$ in SAARC 
and $1.70 \%$ in developed countries. The developed economies are more involved in BASEL III requirement as compare to developing economies so that the results show more coefficient of determination in developed countries.

\begin{tabular}{|c|c|c|}
\hline \multicolumn{3}{|c|}{ Dependent Variable: NIM } \\
\hline VARIABLES & $\begin{array}{l}\text { (SAARC) } \\
\text { NIM }\end{array}$ & $\begin{array}{c}\text { (Developed) } \\
\text { NIM }\end{array}$ \\
\hline NSFR & $\begin{array}{c}0.244 \\
(0.209)\end{array}$ & $\begin{array}{c}-0.310 * * \\
(0.147)\end{array}$ \\
\hline COST & $\begin{array}{c}0.106 \\
(0.0866)\end{array}$ & $\begin{array}{c}0.0279 \\
(0.0364)\end{array}$ \\
\hline EQUITY & $\begin{array}{l}0.00263 \\
(0.0337)\end{array}$ & $\begin{array}{c}-0.0371 \\
(0.0399)\end{array}$ \\
\hline SIZE & $\begin{array}{c}0.168 \\
(0.283)\end{array}$ & $\begin{array}{c}-0.494 * * \\
(0.227)\end{array}$ \\
\hline RGDP & $\begin{array}{c}-1.58 \mathrm{e}-14 * * \\
(7.78 \mathrm{e}-14)\end{array}$ & $\begin{array}{c}-3.80 \mathrm{e}-14 \\
(-0.54)\end{array}$ \\
\hline INF & $\begin{array}{c}0.0174 \\
(0.0605)\end{array}$ & $\begin{array}{l}-0.0813 \\
(0.0585)\end{array}$ \\
\hline Constant & $\begin{array}{c}3.582 * * \\
(1.447)\end{array}$ & $\begin{array}{c}7.320 * * * \\
(1.377)\end{array}$ \\
\hline P Value & 0.215 & 0.035 \\
\hline Observations & 343 & 777 \\
\hline R-squared & 0.028 & 0.017 \\
\hline
\end{tabular}

\section{Conclusion}

The 2007-08 financial market crises that started with the crash of the subprime mortgage led to the turn down in solvency of the banking system in the United States. This has pinched to propose Basel III by Basel Committee on Banking Supervision (BCBS), which applied tough rules and regulations for banks to meet the liquidity. Net Stable Funding Ratio is anticipated to have best performance and a stable way of funding. This helps to banks that focus instead on high quality assets but to retire from investing in low as well as medium quality assets that maintain the banks' profitability.

The finding of the study through analysis that NSFR does have negative association on NIM but it is significant in developed countries and positively insignificant effect in SAARC. Hereafter, the banks having sufficient stable funding as compare to required stable funding, get the benefit of financial profitability in developed economies. In short, our estimations valid the BASEL III stable funding regulations and NSFR as a ratio of stable funding have an ability to enhance the bank's profitability in developed countries as compare to SAARC.Other explanatory variable COST, EQUITY and SIZE have positive impact on bank profitability in developing countries but COST have positive impact on bank profitability and EQUITY as well as SIZE have negative impact on bank profitability in developed 
countries because they follow Basel III very strictly. These results met the expectation of the NSFRProfit link in developed countries as compare to developing countries. Overall results showed, it is evidence that the regulations made in Basel III by central banks as an outcome of the 1997-98 Asian financial that increase the profitability of Malaysian Banks (Commercial). While, this study provides insights of the Net Stable Funding Ratio (NSFR) in SAARC countries as well as developed countries and their implication of new liquidity model set by the Basel III.

\section{References}

Acharya, Viral V., Merrouche, Ouarda, 2013. Precautionary hoarding of liquidity and inter-bank markets: evidence from the sub-prime crisis. Review of Finance 17, 107-160.

Acharya, Viral V., Shin, Hyun Song, Yorulmazer, Tanju, 2011.Crisis resolution and bank liquidity.Review of Financial Studies 24, 2166-2205.

Afonso, Gara.,Kovner, Anna, Schoar, Antoinette, 2011. Stressed, not frozen: the federal funds market in the financial crisis. Journal of Finance 66, 1109-1139.

Allen, Franklin, Gale, Douglas, 2000. Financial contagion.Journal of Political Economy 108, 1-33.

Basel Committee on Banking Supervision, 2010a. Basel III: International Framework for Liquidity Risk Measurement, Standards and Monitoring.

Basel Committee on Banking Supervision, 2010b.

Basel Committee on Banking Supervision, 2010c.Results of the Comprehensive Quantitative Impact Study.

Basel Committee on Banking Supervision, 2013a. Results of the Basel III Monitoring Exercise as of 30 June 2012.

Basel Committee on Banking Supervision, 2013b. Basel III: The Liquidity Coverage Ratio and Liquidity Risk Monitoring Tools.

Basel III: A Global Regulatory Framework for more Resilient Banks and Banking Systems.

Berger, Allen N., Bouwman, Christa H.S., 2009. Bank liquidity creation.Review of Financial Studies 22, 3779-3837.

Brunnermeier, Markus K., 2009. Deciphering the 2007-2008 liquidity and credit crunch.Journal of Economic Perspectives 23, 77-100.

Committee on the Global Financial System, 2010. Funding Patterns and Liquidity Management of Internationally Active Banks, CGFS Papers No 39 (May).

Diamond, Douglas W., Dybvig, Philip H., 1983. Bank runs, deposit insurance, and liquidity. The Journal of Political Economy 91, 401-419.

Diamond, Douglas W., Rajan, G., 2009. The credit crisis: conjectures about causes and remedies. American Economic Review 99, 606-610.

Diamond, Douglas W., Rajan, Raghuram G., 2001. Liquidity risk, liquidity creation, and financial fragility: a theory of banking. The Journal of Political Economy 109, 287-327.

Dietrich, G. Wanzenried, and R. Cole. Why are net-interest margins across countries so different? 2010. Available at SSRN 1542067. 2010.

González, Francisco, 2005. Bank regulation and risk-taking incentives: an international comparison of bank risk. Journal of Banking and Finance 29, 1153-1184.

Gorton, Gary B., 2009. Information, liquidity and the (ongoing) panic of 2007. American Economic Review 99, 567-572.

Hellmann, Thomas F., Murdock, Kevin C., Stiglitz, Joseph E., 2000. Liberalization, moral hazard in banking, and prudential regulation: are capital requirements enough? American Economic Review 90, 147-165.

Huang, Rocco, Ratnovski, Lev, 2011. The dark side of bank wholesale funding.Journal of Financial 
Intermediation 20, 248-263.

Jeitschko, Thomas D., Jeung, Shin Dong, 2007. Incentives for risk-taking in banking -a unified approach.Journal of Banking and Finance 29, 759-777.

King, M. R. (2013). The Basel III net stable funding ratio and bank net interest margins. Journal of Banking \& Finance, 37(11), 4144-4156.

Laeven, Luc, Levine, Ross, 2009. Bank governance, regulation and risk taking.Journal of Financial Economics 93, 259-275.

Milne, Alistair, 2002. Bank capital regulation as an incentive mechanism: implications for portfolio choice. Journal of Banking and Finance 26, 1-23.

Repullo, Rafael, 2004. Capital requirements, market power, and risk-taking in banking. Journal of Financial Intermediation 13, 156-182.

Standard \& Poor's, 2010.Standard \& Poor's Response to the Basel Committee's Proposals on Bank Capital and Liquidity, April 15, 2010.

Strahan, Philip, 2010. Liquidity production in 21st century banking. In: Berger, A.N., Molyneux, P., Wilson, J.O.S. (Eds.), The Oxford Handbook of Banking. Oxford University Press, Oxford. 